A N N A LES

UNIVERSITATIS MARIAE CURIE-SKŁODOWSKA

LUBLIN - POLONIA

VOL. LXII, 2

SECTIO G

2015

JERZY WRATNY

\title{
Prawo do wynagrodzenia za pracę w świetle zasad sprawiedliwości i równości
}

The Right to Remuneration for Work in the Light of the Principles of Justice and Equality

\section{UWAGI WSTĘPNE}

Temat dotyczący prawa do wynagrodzenia za pracę w świetle zasad sprawiedliwości i równości jest niełatwy i wielowątkowy, niemożliwy w zasadzie do wyczerpania $w$ ramach artykułu. Toteż swoją rolę upatruję w szkicowym jedynie przedstawieniu problemów wiążących się z przyjętym zadaniem. Pragnę też podkreślić, że większość wątków, które poruszam, była już szeroko omawiana w licznych publikacjach, zarówno w nauce prawa pracy, jak i w ramach innych dyscyplin. Za przykład można w szczególności uznać szeroko omawianą problematykę równości płac mężczyzn i kobiet za pracę jednakową lub o jednakowej wartości. Dla tych powodów moje rozważania mogą się nie wydać szczególnie odkrywcze. Założeniem było, aby pobudzały one do dyskusji.

Zacznijmy od oczywistego stwierdzenia, że celem „wydarzenia”, jakie stanowi realizacja stosunku pracy jest osiągnięcie określonego wyniku będącego efektem skojarzenia kapitału i pracy ${ }^{1}$. Wynik ten ma przynieść korzyści obu aktorom: pracodawcy i pracownikowi. Towarzyszy temu założenie, że osiągany w procesie

1 Tak jest w przypadku pracy produkcyjnej, co oczywiście nie wyczerpuje wszystkich form zatrudnienia. 
pracy wynik posiada użyteczność dla podmiotów, dla których jest on przeznaczony (zamawiających, klientów, konsumentów), co zatrudnienie czyni sensownym.

Pracodawca zawłaszcza wynik pracy, pobierając dochód od włożonego kapitału. Dochodem pracownika jest natomiast wynagrodzenie za pracę. Relacja między stronami jest więc co do swej istoty cywilistyczna i polega na wzajemnej wymianie świadczeń (facio ut des). Cechuje ona system wytwarzania i pracy dominujący w pewnej epoce historycznej, który jest określany jako system oparty na pracy najemnej.

Pobieranie dochodu od zainwestowanego w proces pracy kapitału nie stanowi przedmiotu zainteresowania prawa pracy; jest to problem istotny w obrębie innych gałęzi prawa, np. podatkowego. Natomiast wynagrodzenie za pracę stanowi, jak wiadomo, centralną kwestię w ramach stanowienia i stosowania prawa pracy.

Według tradycyjnego ujęcia, które moim zdaniem zachowuje ważność, rola prawa $\mathrm{w}$ tym zakresie wynika przede wszystkim z funkcji ochronnej przypisanej tej gałęzi prawa. Ma ono chronić słabszą stronę stosunku pracy (pracownika) przed przewagą strony silniejszej (pracodawcy).

Ta dysproporcja sił wynika, po pierwsze, z faktu, że rynek pracy jest w dominującym stopniu rynkiem pracodawcy, zwłaszcza w warunkach utrzymującego się ciągle na wysokim poziomie wskaźnika bezrobocia. Po drugie, to pracodawca decyduje o stanowisku i miejscu pracy pracownika w zakładzie pracy, co determinuje także wysokość stawek wynagrodzenia oraz inne jego parametry (składniki wynagrodzenia, metody pracy itp.). P o tr ze c i e, pracodawca decyduje o ścieżkach awansu pracownika, uczestnictwie w szkoleniach podnoszących kwalifikacje itp. Krótko mówiąc, pracownik podejmując pracę, dostaje się w gąszcz zależności, a jego umowa, formalnie równoprawna, ma z reguły w dużej mierze charakter adhezyjny. Po czwarte, analizując stan nierównej pozycji stron, należy dostrzec znaczenie wynagrodzenia, które zapewnia utrzymanie osoby pracownika oraz jego rodziny, co określa się mianem funkcji alimentacyjnej i rodzinnej płacy. Pod tym względem, nazwijmy go egzystencjalnym, wynagrodzenie za pracę jest nieporównywalne $\mathrm{z}$ dochodem pobieranym od kapitału zainwestowanego w proces produkcji (zysk pracodawcy/przedsiębiorcy).

Tymi przesłankami kieruje się ustawodawca, ustanawiając przepisy chroniące pod różnymi względami wynagrodzenie za pracę, co stanowi realizację postanowienia Konstytucji mówiącego o ochronie nad pracą Rzeczypospolitej Polskiej (art. 24). W konsekwencji nastąpiło oddalenie się charakteru prawnego stosunku pracy od, będącej jego rdzeniem, konstrukcji cywilistycznej, towarowej.

Polityka ukierunkowana na wzmocnienie słabszej strony zobowiązaniowego stosunku pracy nie jest jedynym motywem stanowienia przepisów chroniących wynagrodzenie za pracę. Ważną przesłanką jest także sprzyjanie zdrowej ekonomii mającej zapewnić, aby społeczeństwo w możliwie najszerszym zakresie utrzymywało się z wytwórczości i pracy bez nadmiernego sięgania do środków 
zabezpieczenia społecznego. Systemy pracy i wynagradzania oraz zabezpieczenia społecznego stanowią bowiem układ naczyń połączonych.

W obrębie państwowej polityki płac mieści się ponadto regulacja i kontrola wydatkowania środków w sferze budżetowej, ograniczanie w sferze publicznej wysokości wynagrodzeń przekraczających poziom uznany za godziwy, przeciwdziałanie zmowom płacowym z uszczerbkiem dla środków publicznych. Wartością chronioną w tych przypadkach jest majątek i dochody Skarbu Państwa oraz innych osób sektora publicznego, w tym instytucji zabezpieczenia społecznego, a więc aktywów służących dobru wspólnemu społeczeństwa. Ważnym komponentem roli państwa jest również polityka antyinflacyjna.

3.

W literaturze z zakresu etyki pracy, szczególnie z kręgu autorów rozwijających tezy katolickiej nauki społecznej, eksponuje się dwie zasady, których harmonijna realizacja miałaby się przyczynić do sprawiedliwego rozwiązania kwestii płacowej.

Są to zasada finalna, wskazująca na powiązanie wynagrodzenia za pracę z zaspokojeniem potrzeb pracownika i jego rodziny, a więc akcentująca funkcję alimentacyjną i rodzinną wynagrodzenia, oraz zasada ka u zaln a, eksponująca związek między wynagrodzeniem za pracę a wydajnością pracownika (wzajemność i ekwiwalentność świadczeń) ${ }^{2}$. Osobno należy wymienić zasadę niedyskryminacji i równego traktowania, sytuującą problem sprawiedliwości płacowej na płaszczyźnie dopuszczalnej dyferencjacji uprawnień między pracownikami danego zakładu pracy czy zespołu roboczego (por. część III).

Wszystkie wymienione wyżej kierunkowe zasady kształtowania wynagrodzeń w zgodzie z postulatami etycznymi nawiązują do idei sprawiedliwości w stosunkach pracy.

Problem sprawiedliwości jest jednym z centralnych tematów filozofii od Arystotelesa ${ }^{3}$ do Rawlsa ${ }^{4}$. W tradycji filozoficznej rozróżnia się za Arystotelesem pojęcie sprawiedliwości rozdzielczej (dystrybutywnej) oraz pojęcie sprawiedliwości wyrównawczej (wzajemnej, komutatywnej). Jak pisze Stagiryta, sprawiedliwość

2 Por. Z. Majka, Etyka życia gospodarczego, Wrocław 1982, s. 165 i n.; L. Dyczewski, Płaca sprawiedliwa i stuszna, „Ethos” 1995, nr 4, s. 113-121; idem, Stuszna i sprawiedliwa placa w ujęciu katolickiej nauki społecznej, [w:] Prawo do płacy godziwej, Warszawa 1994; J. Wratny, Koncepcja pracy sprawiedliwej a niektóre aktualne problemy prawa pracy i polityki płac $w$ Polsce, „Ethos” 1995, nr 4, s. 133-141; M. Nowak, Wynagrodzenie za prace, Warszawa 2014, s. 45-81.

Arystoteles, Etyka nikomachejska, Warszawa 1956.

4 J. Rawls, Teoria sprawiedliwości, Warszawa 1994. 
dystrybutywna odnosi się „do rozdziału społecznych ciężarów i dóbr, zaś ze sprawiedliwością wyrównawczą mamy do czynienia [...] w rodzących zobowiązania stosunkach między ludźmi”'s.

Na nasz użytek przyjmijmy także odnoszące się do sprawiedliwości rozdzielczej rozróżnienie pojęcia sprawiedliwości formalnej i konkretnej (materialnej). Pierwsze oznacza zasadę działania, w myśl której osoby należące do tej samej kategorii istotnej powinny być traktowane jednakowo ${ }^{6}$. Kategoria istotna to grupa ludzka wyodrębniona na podstawie jednolitego kryterium, czyli skupiająca jednostki posiadające tę samą cechę istotną (relewantną). Cechą sprawiedliwości formalnej jest stosowanie jednolitej zasady postępowania wobec wszystkich bez wyjątków członków kategorii istotnej. Równość ta stanowi konsekwencję logiczną reguły jednakowego traktowania wszystkich członków kategorii istotnej ${ }^{7}$, w zasadzie obojętne jest natomiast według jakiego kryterium ma być taka kategoria utworzona. $\mathrm{W}$ istocie rzeczy mamy w tym przypadku do czynienia $\mathrm{z}$ redukcją pojęcia sprawiedliwości do zasady równości.

W przeciwieństwie do sprawiedliwości formalnej (abstrakcyjnej), w koncepcji sprawiedliwości konkretnej (materialnej) równorzędne znaczenie ma określenie cechy relewantnej, według której ustanawia się kategorię istotną osób, które powinny być traktowane jednakowo. Trzeba się zatem odnieść do skali wartości. W koncepcji sprawiedliwości materialnej nacisk jest położony na dokonywanie wyborów o charakterze aksjologicznym.

Na skali wartości mogą występować różne formuły sprawiedliwości, m.in.: „każdemu to samo” (egalitaryzm), „każdemu według zasług, dzieł, pracy, potrzeb”, „każdemu według pozycji” (elitaryzm) ${ }^{8}$. Cechą wspólną tego rodzaju formuł sprawiedliwości materialnej jest to, że nawiązują do kryteriów mających oparcie w określonych systemach wartości, które nie muszą być przez wszystkich w równym stopniu podzielane? .

\footnotetext{
5 Arystoteles, op. cit., s. 172.

6 Por. Ch. Perelman, O sprawiedliwości, Warszawa 1959, s. 37, 77.

7 Czyn sprawiedliwy w rozumieniu sprawiedliwości formalnej to zachowanie się zgodnie z konkluzją sylogizmu imperatywnego, którego przesłankę większą stanowi jakakolwiek reguła postępowania wobec jednostek należących do kategorii istotnej, zaś przesłankę mniejszą - zaliczenie konkretnej jednostki do tej kategorii istotnej ze względu na posiadanie przez nią cechy istotnej. Jeżeli wszystkie A powinny być B i jeżeli X należy do A, to X powinien być tak samo traktowany, jak B. Ibidem, s. 77-78. Według ogólnej koncepcji sprawiedliwości Rawlsa: „Wszelkie społeczne wartości - wolności i możliwości, dochód i bogactwo" oraz podstawy szacunku dla samego siebie mają być równo rozdzielone, chyba że nierówna dystrybucja jakichkolwiek (czy też wszystkich) spośród tych wartości jest korzystna dla każdego. Niesprawiedliwość to nierówności, „które nie są z korzyścią dla wszystkich”. J. Rawls, op. cit., s. 89.

8 Ch. Perelman, op. cit., s. 38 i n.

9 Na wielość sposobów rozumienia sprawiedliwości (wartości składających się na to pojęcie) w różnych wierzeniach i doktrynach zwraca uwagę W. Sanetra, w związku z czym poddaje krytyce
} 
Arbitralność wyboru wartości nadrzędnych, zależnie od przekonań osoby wyrażającej sąd etyczny na temat tego, co jest sprawiedliwe, jest eliminowana, gdy posłużymy się pojęciem sprawiedliwości p rawnej. Jej odbiciem jest legalistyczna formuła „każdemu według tego, co przyznaje mu prawo (suum cuique)”. Według tej dewizy „sprawiedliwość” oznacza „ściśle zgodnie z prawem”" Między moralnym poczuciem sprawiedliwości a prawnym jej rozumieniem zachodzą wzajemne interakcje niewykluczające konfliktów, które w skrajnym ujęciu wyraża paradoks summum ius, summa iniuria.

\section{CZYMŻE JEST WIĘC PŁACA SPRAWIEDLIWA?}

Wyrazem płacy sprawiedliwej jako płacy nawiązującej do potrzeb jest wspomniana wyżej zasada finalna. Według Jana Pawła II rola płacy polega przede wszystkim na tym, że pozostaje ona „konkretnym środkiem, dzięki któremu ogromna większość ludzi może korzystać z owych dóbr, które są przeznaczone do powszechnego używania" ${ }^{11}$. Papież kładzie nacisk na pierwszeństwo osoby pracownika przed pracą $\mathrm{w}$ znaczeniu przedmiotowym, również przed oceną wyników pracy. Jak pisze w Centesimus Annus, „ważniejsze niż logika wymiany równowartości i niż różne formy sprawiedliwości, które się z tym wiążą, jest to, co należy się człowiekowi, ponieważ jest człowiekiem ze względu na jego wzniosłą godność" ${ }^{2}$. Płaca powinna w każdym wypadku zapewniać pracownikowi niezbędne środki egzystencji. Nie chodzi przy tym tylko o minimum tych środków, ale o zapewnienie poziomu życia ,prawdziwie ludzkiego”, odpowiadającego godności osoby ludzkiej. Aksjologia ta wyklucza możliwość traktowania wynagrodzenia za pracę w kategoriach zapłaty za dostarczony przez pracownika „towar”.

Powyższe postulaty, odzwierciedlające ideę płacy życiowej, są uzupełniane przez ideę płacy rodzinnej wyciskającej szczególne piętno na nauczaniu społecznym Kościoła w tej dziedzinie. Według Jana Pawła II „sprawiedliwa płaca staje się w każdym wypadku konkretnym sprawdzianem sprawiedliwości całego

\footnotetext{
zawarte w preambule do Konstytucji RP z 1997 roku określenie sprawiedliwości jako „wartości uniwersalnej”. Por. W. Sanetra, Ogólnie o aksjologicznych podstawach prawa pracy, „Praca i Zabezpieczenie Społeczne" 2013, nr 11.

10 Rygoryzm tak rozumianej sprawiedliwości łagodzić ma według Arystotelesa (op. cit., s. 199) pojęcie prawości, które można utożsamić ze słusznością (equitas). Pozwala ona łagodzić bezwzględną równość w ramach kategorii określonych prawem przez uwzględnienie okoliczności indywidualnego przypadku, których prawo nie jest w stanie uregulować.

11 Jan Paweł II, Laborem exercens, Wrocław 1983 (dalej: LE).

12 Idem, Centesimus Annus (w setna rocznicę Encykliki Rerum Novarum), [w:] Dzieła zebrane, Kraków 2006.
} 
ustroju społeczno-ekonomicznego", dodając, że „sprawdzian ten dotyczy przede wszystkim rodziny"13.

6.

Pod wpływem różnych prądów ideowych, w tym zwłaszcza doktryny katolickiej i socjalistycznej, postulaty płacy życiowej i rodzinnej zostały przyswojone w prawie międzynarodowym i europejskim. Kluczowe znaczenie w tej dziedzinie ma koncepcja wynagrodzenia godziwego (fair remuneration) definiowanego w art. 4 ust. 1 Europejskiej Karty Społecznej ${ }^{14}$ jako w szczególności wynagrodzenie mające zapewnić pracownikom i ich rodzinom właściwy (przyzwoity) poziom życia (decent standard of living) ${ }^{15}$.

Zastosowanie do tego samego przypadku postulatów „według pracy” i ,według potrzeb" może, co oczywiste, prowadzić do rozbieżnych wyników. Toteż należy podkreślić, że w idei płacy życiowej i rodzinnej, rozumianej jako postulat prawny, chodzi o pewien pułap potrzeb podstawowych. Położenie na ten aspekt nacisku $\mathrm{w}$ doktrynach oraz $\mathrm{w}$ prawie międzynarodowym i europejskim wynika z okoliczności, iż jest to par excellence zagadnienie polityki społecznej, za kierunek której w ostatecznym rozrachunku odpowiedzialne jest państwo, podczas gdy na zapewnienie ekwiwalentności wynagrodzeń do wkładu pracy (realizacja zasady kauzalnej, o czym niżej) państwo ma wpływ ograniczony i pośredni, gdyż zasada ta spełnia się w sferze umów.

Ingerencja państwa w tym zakresie ma miejsce jedynie wobec najmniej zarabiających pracowników i ich rodzin. Wpływanie na system wynagrodzeń przez nawiązywanie do płacy życiowej i rodzinnej stanowi więc jedynie podyktowaną postulatami sprawiedliwości rozdzielczej korekturę zasady kauzalnej w dolnych przedziałach płac. Ingerencja państwa w tym zakresie nie może wykraczać poza niezbędne ramy (zasada pomocniczości). W grupach pracowników lepiej uposażonych postulaty płacy życiowej i rodzinnej są realizowane samoczynnie przez płacę mniej lub bardziej ekwiwalentną do wkładu pracy, kształtowaną na drodze układów zbiorowych i umów indywidualnych.

13 Jan Paweł II, LE. Por. J. Wratny, Płaca rodzinna (szkic zagadnienia), [w:] Prawo pracy a rodzina. Układy zbiorowe pracy, pod red. T. Liszcz, Warszawa 1996, Warszawa 1996.

14 Dokument Rady Europy z 18 października 1961 roku, którym Polska związała się selektywnie (dalej: EKS). Europejska Karta Społeczna ma być zastępowana stopniowo przez Zrewidowaną Europejską Kartę Społeczną z 3 maja 1996 roku, w której powtórzono treść postanowienia art. 4 w niezmienionej postaci. Oba dokumenty zostały opublikowane w zbiorze: Podstawowe dokumenty Rady Europy z dziedziny polityki społecznej, wyb. i oprac. R. Henczel, J. Maciejewska, Warszawa 1997.

15 Polska nie związała się tym postanowieniem z uwagi na zbyt niski poziom płacy minimalnej w naszym kraju. 
Interpretacja Europejskiej Karty Społecznej prowadzi do wniosku, że określenie „płaca godziwa” jest w zasadzie synonimem płacy minimalnej, o ile tylko płaca taka spełnia kryteria, o których mowa w Karcie. Toteż instytucję prawną wynagrodzenia minimalnego za pracę, ustalanego w wielu krajach przez państwo bądź na drodze porozumień organizacji partnerów społecznych, należy traktować jako realizację postulatu wiązania płac w niższych grupach dochodowych z potrzebami pracownika i jego rodziny ${ }^{16}$. Zauważmy, że w wykładni organów kontrolnych EKS wysokość wynagrodzenia godziwego, rozumianego jako wynagrodzenie minimalne, jest odnoszona (przy wszystkich zastrzeżeniach i modyfikacjach) do wysokości wynagrodzenia przeciętnego w danym kraju, stanowi zatem określony udział w tej wielkości makroekonomicznej. Oznacza to, że instytucja płacy minimalnej powinna zapewniać także mniej zarabiającym członkom społeczeństwa uczestnictwo w ogólnym wzroście dobrobytu.

8.

W Polsce prawo do godziwego wynagrodzenia kojarzone jest przede wszystkim (choć niewyłącznie) z ustalaniem minimalnego wynagrodzenia za pracę (por. art. 13 k.p.). Koncepcja tego wynagrodzenia i praktyka ustalania jego wysokości budzą jednak liczne kontrowersje.

Wysokość wynagrodzenia minimalnego, mimo corocznej weryfikacji w wyniku przetargów w Trójstronnej Komisji do Spraw Społeczno-Gospodarczych ${ }^{17}$, ciągle odbiega od postulowanych przez organizacje międzynarodowe wskaźników, co jest powodem niezwiązania się Polski kluczowym postanowieniem EKS definiującym godziwość wynagrodzenia za pracę. Brakuje przy tym konsensusu, jaka powinna być ścieżka dojścia do modelu docelowego ${ }^{18}$.

16 W prawie międzynarodowym por. Konwencję nr 131 Międzynarodowej Organizacji Pracy z 1970 roku, dotyczącą ustalania płac minimalnych, zwłaszcza w odniesieniu do krajów rozwijających się (nieratyfikowaną przez Polskę) oraz uzupełniające Konwencję Zlecenie nr 135. Dokumenty opublikowano w zbiorze: Konwencje i zalecenia Międzynarodowej Organizacji Pracy 1919-2012, t. 2: 1974-2012, Ministerstwo Pracy i Polityki Społecznej, Warszawa 2014. Według ust. 1 Zalecenia nr 135: „Ustalanie płac minimalnych powinno stanowić jeden z elementów polityki mającej na celu przezwyciężenie ubóstwa oraz zaspokojenie potrzeb wszystkich pracowników i ich rodzin".

17 Obecnie funkcje tego gremium ma przejąć tzw. Rada Dialogu Społecznego. W chwili składania artykułu do druku projekt ustawy o Radzie Dialogu Społecznego i innych instytucjach dialogu społecznego znajdował się na końcowym etapie prac parlamentarnych.

18 Według niektórych propozycji mogłoby nim być minimum socjalne wystarczające przynajmniej do utrzymania jednej osoby, a więc bez uwzględniania aspektu rodzinnego jako niemożliwego do przyjęcia w aktualnych warunkach, co nie wyklucza nadania płacy minimalnej charakteru rodzinnego, gdy sytuacja ekonomiczna na to pozwoli. Z pola widzenia nie należy przy tym tracić 
Według mojej oceny kluczowym zagadnieniem de lege ferenda jest określenie zasięgu podmiotowego stosowania płacy minimalnej, mianowicie czy z dobrodziejstwa tej instytucji nie powinny, poza pracownikami, skorzystać także osoby zatrudnione poza stosunkiem pracy, a więc przede wszystkim rzesza osób wykonujących pracę na podstawie umów cywilnoprawnych. Za takim rozwiązaniem przemawia podobieństwo statusów obu grup, co uzasadnia łączne ich zaliczenie do tej samej kategorii istotnej - utrzymujących się z pracy „,własnych rąk”. Wniosek ten wspiera również argumentacja wywiedziona z Konstytucji ${ }^{19}$.

9.

Wzorzec godziwego wynagrodzenia w świetle orzecznictwa Sądu Najwyższego i w zgodzie z pojemną treścią art. 13 k.p. nie służy wyłącznie ustalaniu minimalnego wynagrodzenia za pracę. $\mathrm{W}$ pewnym wybiórczym zakresie wzorzec ten odnosi się też do wynagrodzeń najwyższych lub wygórowanych oraz do problemu ekwiwalentności świadczeń.

Problem odgórnego ustalania pułapów wynagrodzenia dotyczy w zasadzie zakładów sfery publicznej. Kumulują się wówczas argumenty wywodzone z pojęcia godziwości oraz argumenty nawiązujące do potrzeby racjonalnego zarządzania aktywami będącymi w gestii publicznej w celu realizacji zadań ogólnospołecznych.

W tym kontekście należy wymienić ustawową reglamentację płac w sferze budżetowej wraz z przepisami dotyczącymi przestrzegania dyscypliny finansów publicznych czy tzw. ustawę kominową ${ }^{20}$. Formuła sprawiedliwości, adresowana do osób zajmujących wysokie stanowiska kierownicze w administracji i gospodarce, mogłaby w tym przypadku brzmieć: „Według przyzwoitości w czerpaniu na wynagrodzenia ze środków publicznych".

Z kolei w orzecznictwie zaakcentowano tezę, według której autonomia woli stron umowy o pracę podlega jedynie względnej ochronie, ponieważ strony obo-

znaczenia płacy jako elementu kosztów dla pracodawcy oraz funkcji motywacyjnej wynagrodzenia za pracę.

19 Zwolennikiem objęcia wynagrodzeniem minimalnym osób zatrudnionych na podstawie umów cywilnoprawnych jest A. Sobczyk (por. idem, Wynagrodzenie minimalne zleceniobiorców, „Praca i Zabezpieczenie Społeczne” 2012, nr 8; idem, Prawo pracy w świetle Konstytucji RP, t. 2: Wybrane problemy i instytucje prawa pracy a konstytucyjne prawa $i$ wolności człowieka, Warszawa 2013, s. 39-46). Sprawa ta była przedmiotem debaty w redakcji „Gazety Prawnej” (zob. T. Zalewski, Płaca minimalna nie przy każdym zleceniu, „Dziennik Gazeta Prawna”, 05.11.2014). W debacie poparłem ideę szerszego zastosowania gwarancji wynagrodzenia minimalnego, zwracając jednocześnie uwagę na trudności realizacyjne takiego projektu. Ochronę wynagrodzeń zleceniodawców w pewnym stopniu mogą przy tym zapewniać przepisy Kodeksu cywilnego, np. przepis o postępowaniu w sprawie wyzysku (art. 388 k.c.).

20 Ustawa z dnia 3 marca 2000 roku o wynagradzaniu osób kierujących niektórymi podmiotami prawnymi (t.j. Dz.U. z 2013 roku, poz. 1645). 
wiązane są nie tylko do respektowania własnego interesu jednostkowego, ale powinny mieć na względzie także interes publiczny. Wymagają tego zasady współżycia społecznego i nakaz godziwości wynagrodzenia (art. 13 k.p.) $)^{21}$. Zarówno zatem zasada „każdemu według (minimum) potrzeb”, jak i zasada przyzwoitości - obie wywodzone z koncepcji wynagrodzenia godziwego - mają charakter korygujący wobec zasady swobody umów. Jest to wnoszona do systemu płac korekta wynikająca z idei sprawiedliwości rozdzielczej.

Należy jeszcze raz podkreślić, że wykorzystywanie pojęcia godziwości w celu moderowania wysokości płac wygórowanych ma miejsce w zakładach pracy sfery publicznej ${ }^{22}$. Natomiast odnosząc się do polityki płac w niepublicznej spółce prawa handlowego, Sąd Najwyższy stwierdził, że „,art. 13 k.p. nie reglamentuje wysokości wynagrodzenia pracownika. Przyznanie pracownikowi świadczenia nienależnie wysokiego z reguły nie powinno być przyczyną odmowy jego zasądzenia. Wymaga tego bezpieczeństwo obrotu, zasada pacta sunt servan$d a$ oraz ochrona pracownika"23.

Zdarzającym się w praktyce zjawiskiem są zmowy płacowe miedzy pracodawcą a pracownikiem, których celem jest wywindowanie wysokości świadczeń $\mathrm{z}$ ubezpieczenia społecznego, dla których podstawą wymiaru jest wynagrodzenie za pracę (np. zasiłki macierzyńskie). Zawieranie umów o pracę dla pozoru w celu wyłudzenia świadczenia bądź rażąco wysokie, nieadekwatne do rodzaju pracy, ustalenie wysokości wynagrodzenia może być przedmiotem kontroli jako „świadome osiąganie nieuzasadnionych korzyści z systemu ubezpieczeń społecznych kosztem innych uczestników tego systemu"24. Zmusza do zastanowienia rosnąca liczba wytaczanych na tym tle spraw sądowych.

10.

Ingerencja państwa $\mathrm{w}$ dziedzinę wynagrodzeń za pracę, podyktowana względami sprawiedliwości rozdzielczej (oraz innymi celami, jak np. polityka antyinflacyjna), nie przekreśla roli zasady kauzalnej, według której płaca powinna pozostawać w proporcji do wyników pracy czy szerzej - do korzyści, jakie praco-

21 Por. następujące orzeczenia SN: wyrok z dnia 7 sierpnia 2001 roku, I PKN 563/00, OSNP 2002/4/90; wyrok z dnia 20 czerwca 2012 roku, I PK 13/12, LEX nr 1243001; wyrok z dnia 23 stycznia 2014 roku, I UK 302/13, LEX nr 1503234. Por. też wyroki sądów apelacyjnych w Krakowie: $\mathrm{z}$ dnia 20 września 2012 roku, III AUa 420/12, LEX nr 1220514; z dnia 25 września 2012 roku, III AUa 398/12, LEX nr 1223252; z dnia 29 stycznia 2013 roku, III AUa 493/12, LEX 1280382; wyrok Sądu Apelacyjnego w Katowicach z dnia 4 kwietnia 2013 roku, III AUa 759/12, LEX nr 1313278; wyrok Sądu Apelacyjnego w Rzeszowie z dnia 10 września 2014 roku, III AUa 279/14, LEX nr 1506730.

22 Por. przytoczony wyżej wyrok SN z dnia 7 sierpnia 2001 roku, I PKN 563/00.

23 Por. wyrok SN z dnia 20 marca 2009 roku, I PK 181/08, LEX nr 707849.

24 Cytowany wyżej wyrok SN z dnia 23 stycznia 2014 roku, I UK 302/13. 
dawca czerpie z zatrudnienia pracownika ${ }^{25}$. W tym przypadku mamy do czynienia z aspektem sprawiedliwości zamiennej (wyrównawczej, komutatywnej). Podmiot zatrudniający jest zobowiązany do świadczenia będącego równowartością świadczenia pracy. Tę synalagmatyczną właściwość wynagrodzenia za pracę określa się jako cechę wzajemności (facio ut des) i ekwiwalentności wynagrodzenia do wkładu pracy.

W tym miejscu rozważań pojawia się problem sposobu mierzenia pracy i obliczania zarobku pracownika oraz kwestia znaczenia prawnego takiego pomiaru. Pomiar sprowadza się, po pierwsze, do oceny pracy, a więc - jak się na ogół przyjmuje - do cech złożoności, ciężkości pracy, odpowiedzialności i warunków, w jakich praca jest świadczona; następnie dotyczy oceny pracownika, czyli kwalifikacji zawodowych, doświadczenia, predyspozycji oraz innych cech świadczących o jego przydatności do wykonywania pracy danego rodzaju; wreszcie dotyczy oceny samego świadczenia pracy, czyli osiągania przez pracownika wyników ilościowych i jakościowych. Przy pracach o niewymiernych lub trudno wymiernych efektach podstawowym miernikiem świadczenia pracy jest czas jej wykonywania. Kryteria, według których powinny być ustalane wynagrodzenia, zostały (niewyczerpująco) wskazane w przepisie art. 78 § 1 k.p., który w sposób najbardziej bezpośredni odnosi się do cechy ekwiwalentności wynagrodzenia za pracę.

Sposoby postępowania w zakresie pomiaru pracy służą przybliżeniu się w danej sytuacji do obiektywnego wzorca płacy ekwiwalentnej względem nakładu pracy, a więc do spełnienia postulatu sprawiedliwości wyrównawczej. Metodą, która pozwala na porównywanie ze sobą różnych rodzajów pracy (stanowisk) w ramach danego zakładu pracy w celu zobiektywizowania wzorca ekwiwalentności, jest wartościowanie pracy. Stanowi ono pożyteczny instrument zapewniający sprawiedliwość i racjonalność decyzji płacowych. Może też być ważkim, bo obiektywnie uzasadnionym, argumentem w sporach spowodowanych podniesieniem zarzutu nierównego traktowania pracowników (por. uwagi w pkt. 14).

W kontekście sprawiedliwości wymiennej nie należy tracić z pola widzenia roli umowy o pracę. Zasadą rządzącą stosunkami pracy, szczególnie w sektorze prywatnym, jest bowiem - mimo wszelkich możliwych zastrzeżeń - swoboda umów (por. art. $353^{1}$ k.c.). Do puli wartości, związanych m.in. ze sprawiedliwo-

${ }^{25}$ Chociaż pojęcie zasady kauzalnej w cytowanej literaturze formułowane jest na gruncie filozofii społecznej, to zarazem można doszukiwać się odniesienia do cywilnoprawnego pojęcia kauzy czynności prawnej. Celem przysporzenia na rzecz pracownika jest uzyskanie wzajemnego przysporzenia na rzecz pracodawcy (causa acquirendi vel obligandi). Natomiast wypłata każdorazowej transzy wynagrodzenia za pracę świadczoną w określonym przedziale czasu (np. za przepracowany miesiąc) służy zwolnieniu się przez przysparzającego pracodawcę z długu będącego wierzytelnością pracowniczą (causa solvendi). Innymi słowy, kauzalność określa charakter prawny i sposób funkcjonowania stosunku pracy. W sprawie klasyfikacji przyczyn czynności prawnych por. S. Grzybowski, System prawa cywilnego. Część ogólna, Wrocław 1974, s. 496-504. 
ścią w dziedzinie płac, należy więc dołączyć poszanowanie podmiotowości i autonomii woli stron umowy o pracę ${ }^{26}$. Przepisy płacowe ograniczają wprawdzie - ze względu na potrzebę ochrony słabszego partnera przed silniejszym i inne przesłanki - swobodę umów w zakresie płac, ale jej nie uchylają.

11.

Cecha ekwiwalentności jako w pełni obiektywny wzorzec sprawiedliwego wynagrodzenia za pracę w sferze roszczeń odgrywa rolę o tyle, o ile ustalenia dotyczące tego wzorca znajdą odbicie w treści umowy o pracę oraz $\mathrm{w}$ treści autonomicznych źródeł prawa pracy. Wartościowanie pracy, nawet najrzetelniej przeprowadzone, nie jest dla pracownika źródłem roszczeń. Zgodnie z tezą wielokrotnie powtarzaną w orzecznictwie ,z prawa do godziwego wynagrodzenia pracownik nie może wywodzić roszczenia o podwyższenie wynagrodzenia za pracę, poza żądaniem jego wyrównania do poziomu wynagrodzenia minimalnego" ${ }^{27}$. Toteż przytoczona $\mathrm{w}$ jednym $\mathrm{z}$ orzeczeń charakterystyka wynagrodzenia godziwego przez zestawienie epitetów: „należne”, „właściwe”, „odpowiednie”, „rzetelne”, „uczciwe” i „sprawiedliwe”, „zachowujące cechy ekwiwalentności do pracy”28, ma charakter w zasadzie tylko moralny.

Moralne postulaty sprawiedliwości adresowane w stosunku do płacy mającej odpowiadać kryterium ekwiwalentności można mnożyć, podnosząc m.in. takie kwestie, jak zachowanie realnej wartości płac w warunkach inflacji, zapobieganie nadmiernym rozpiętościom indywidualnych wynagrodzeń, podwyższanie wynagrodzeń w razie poprawy kondycji ekonomicznej przedsiębiorstwa i vice versa - dopuszczenie do ich redukcji, gdy kondycja ta ulega pogorszeniu ${ }^{29}$.

Etyczne postulaty pod adresem systemów płac są przedmiotem przetargów przy stanowieniu układów zbiorowych pracy (szczególnie szczebla zakładowego) oraz regulaminów wynagradzania ${ }^{30}$. Związki zawodowe, negocjując te dokumenty, dają wyraz sprawiedliwości rozumianej jako poczucie sprawiedliwości

${ }^{26} \mathrm{~W}$ okresie totalitarnego socjalizmu czołowi przedstawiciele nauki prawa pracy (M. Święcicki, W. Szubert i inni) podkreślali rolę umowy i związanych z nią wartości dla rozwoju stosunków pracy w postępowym kierunku.

27 Por. następujące orzeczenia SN: wyrok z dnia 29 maja 2006 roku, I PK 230/05, OSNP 2007/11-12, poz. 155; wyrok z dnia 25 sierpnia 2010 roku, II PK 50/10, LEX nr 707421; wyrok z dnia 10 lutego 2011 roku, II PK 194/10, LEX nr 811846; wyrok z dnia 12 lipca 2011 roku, II PK 18/11, LEX nr 1044007.

28 Wyrok Sądu Apelacyjnego w Krakowie z dnia 25 września 2012 roku, III AUa 398/12, LEX nr 1223252.

29 Całościowy model płacy godziwej, oparty na obiektywnych funkcjach płacy, społecznej nauce Kościoła, wynikach badań opinii pracowniczych oraz dorobku teorii, przedstawia J. Meller, Ptaca godziwa i jej determinanty, [w:] Prawo do pracy godziwej, Warszawa 1994, s. 104-107.

30 Por. art. 78 § 2 k.p., odsyłający do pozaustawowych źródeł określania wynagrodzeń. 
załóg, które są przez nie reprezentowane ${ }^{31}$. Strona pracodawcza z kolei zwraca uwagę na uwarunkowania rynkowe i ekonomiczne, w jakich działa przedsiębiorstwo. Problemem jest kryzys związkowej reprezentacji pracujących, co w większości zakładów pracy uniemożliwia dojście do głosu przekonań dotyczących tego, jakie płace pracownicy uznają za sprawiedliwe.

\section{ZASADA RÓWNOŚCI}

12.

Dotychczasowe rozważania były skupione na problemach aksjologicznych wynagrodzenia należnego indywidualnemu pracownikowi bez uwzględnienia kontekstu społecznego, czyli bez wzięcia pod uwagę okoliczności, że pracownik świadczy pracę wespół z innymi. Stwierdziliśmy dotychczas, że wynagrodzenie za pracę, kojarzone z pojęciem płacy godziwej, powinno w szczególności uwzględniać dwa postulaty etyczne, a mianowicie zaspokojenie potrzeb (przynajmniej na poziomie podstawowym) pracownika i jego rodziny oraz odpowiadać (przynajmniej w przybliżeniu) zasadzie równowartości świadczeń wzajemnych, co wyraża slogan ,jaka praca taka płaca”. Szczególnym aspektem płacy sprawiedliwej jest wszakże również postulat niedyskryminacji i równego traktowania, co stawia problem sprawiedliwości w sferze relacji ponadjednostkowych. Mamy w tym przypadku do czynienia z zastosowaniem reguły, w myśl której wszystkie osoby posiadające określoną (relewantną) cechę, a więc należące do tej samej kategorii istotnej, powinny być traktowane jednakowo. Dotychczasowe rozważania wymagają zatem wzbogacenia o wymiar sprawiedliwości formalnej (por. uwagi w pkt. 4).

Intuicja i retrospekcja podpowiada, że taki nakaz jednakowego traktowania szczególnie wyraźnie wiąże się z odczuwaniem przez człowieka, że jest on przez innych traktowany sprawiedliwie. W nawiązaniu do definicji sprawiedliwości i sposobu jej przeżywania można stwierdzić, że jest to postulat etyczny powszechnie uznawany za oczywisty ${ }^{32}$. W pewnym stopniu podlega on jurydyzacji, czego

31 Jak stwierdza J. Meller (op. cit., s. 107): „Płaca słuszna to ostatecznie płaca społecznie sprawiedliwa w odczuciu pracowników".

32 Jak pisze W. Sadurski (Równość wobec prawa, „Państwo i Prawo” 1978, nr 8-9, s. 64), określenie „równość” w odróżnieniu od określeń „sprawiedliwość” czy „,łłuszność”, „spełnia doskonale zarówno wymogi angażowania emocjonalnego, jak i pewnej rzeczowości”. W literaturze prawa pracy równości w stosunkach pracy dotyczą m.in. następujące pozycje: J. Skoczyński, Zasada równego traktowania pracowników, „Praca i Zabezpieczenie Społeczne”1999, nr 7-8; B. Wagner, Zasada równego traktowania i niedyskryminacji pracowników, „Praca i Zabezpieczenie Społeczne” 2002, nr 3; A. Tyc, Możliwość zakwalifikowania interesu ekonomicznego jako obiektywnego kryterium uzasadniającego zróżnicowanie pracowników a realizacja zasad równości i sprawiedliwości, [w:] Studia z zakresu prawa pracy i polityki społecznej, pod red. A. Świątkowskiego, Kraków 2013. 
dowodzą liczne deklaracje oraz dokumenty prawa międzynarodowego i europejskiego zakazujące praktyk dyskryminacyjnych w ogólności oraz w odniesieniu do określonych sytuacji społecznych, w tym dotyczących zatrudnienia i stosunków pracy. Dokumenty mówiące o zakazie dyskryminacji w tej dziedzinie zostały implementowane do polskiego ustawodawstwa, w związku z czym można uznać, że Polska wywiązała się, przynajmniej gdy chodzi o zapewnienie tzw. równości w prawie ${ }^{33}$, ze zobowiązań międzynarodowych i europejskich ${ }^{34}$.

13.

Kluczowym przepisem dotyczącym równości w zakresie płac ${ }^{35}$ jest art. $18^{3 \mathrm{c}}$ k.p. Zgodnie z $\S 1$ tego przepisu pracownicy mają prawo do jednakowego wynagrodzenia za jednakową pracę lub za pracę o jednakowej wartości ${ }^{36}$. Wykład-

33 „Równość w prawie” to nakaz kształtowania przepisów prawa zgodnie z zasadą równości w odróżnieniu od „równości wobec prawa”, będącej nakazem równego stosowania prawa. Por. w szczególności: W. Sadurski, op. cit.

34 Pomijam w tym miejscu zastrzeżenia podnoszone wobec redakcji przepisów antydyskryminacyjnych w Kodeksie pracy (art. $11^{2}$ i $11^{3}$ oraz rozdział IIa w dziale pierwszym k.p.), dotyczące m.in. niejasnej delimitacji pojęć zakazu dyskryminacji i nakazu równego traktowania czy też problem katalogu kryteriów dyskryminacji: enumeracja czy lista otwarta.

${ }_{35}$ Zagadnienie przeciwdziałania nierównemu traktowaniu w zakresie płac, w szczególności mężczyzn i kobiet, było przedmiotem następujących opracowań: I. Boruta, Prawo pracownic do jednakowego wynagrodzenia, „Praca i Zabezpieczenie Społeczne” 1991, nr 11-23; eadem, Zakaz dyskryminacji płacowej ze względu na płeć w prawie WE, „Praca i Zabezpieczenie Społeczne” 1995, nr 11; T. Liszcz, Równość kobiet i mężczyzn w k.p., „Praca i Zabezpieczenie Społeczne” 2002, nr 2; M. Wandzel, Równe traktowanie mężczyzn i kobiet, Kraków 2003; idem, Wynagrodzenie proporcjonalne do wartości pracy jako realizacja zasady równego wynagradzania pracowników za taka sama pracę lub pracę o takiej samej wartości w prawie wspólnotowym, „Studia z Zakresu Prawa Pracy i Polityki Społecznej” 2009; K. Świderska, Zakaz dyskryminacji w wynagradzaniu, „Monitor Prawniczy” 2004, nr 5; K. Walczak, Zakaz dyskryminacji w wynagrodzeniu w świetle przepisów prawa i praktyka jego wdrażania, „Studia z Zakresu Prawa Pracy i Polityki Społecznej” 2005, nr 1; M. Głogowska, Zakres przedmiotowy zakazu dyskryminacji w wynagradzaniu ze względu na pteć w orzecznictwie ETS, „Studia z Zakresu Prawa Pracy i Polityki Społecznej" 2012; K. Walczak, Regionalizacja wynagrodzeń a zasada niedyskryminacji pracowników, „Gdańskie Studia Prawnicze” 2013, t. XXX, s. 225-232; M. Głogowska, Płeć jako kryterium dyskryminacji lub dyferencjacji w zakresie wynagradzania, „Studia z Zakresu Prawa Pracy i Polityki Społecznej” 2014. Por. ponadto przeglądy orzecznictwa: Dyskryminacja i równość w ustalaniu wynagrodzenia w orzecznictwie SN, „Praca i Zabezpieczenie Społeczne” 2005, nr 1; Dyskryminacja w wynagrodzeniu w orzecznictwie SN, „Praca i Zabezpieczenie Społeczne” 2007, nr 7; Równość kobiet i mężczyzn w wynagrodzeniach $w$ świetle orzecznictwa TSUE, „Praca i Zabezpieczenie Społeczne” 2013, nr 4.

36 Nie rozważam w tym miejscu kwestii, jaką w kodeksie pracy jest rozszerzenie kręgu podmiotów, wobec których ma obowiązywać reguła ,jednakowego wynagrodzenia" na ogół pracowników. W prawie międzynarodowym i europejskim reguła ta w brzmieniu odpowiadającym treści art. $18^{3 \mathrm{c}} \mathrm{k} . p$. odnoszona jest do równego wynagradzania mężczyzn i kobiet (por. konwencję nr $100 \mathrm{MOP}$ z 1951 roku, art. 157 Traktatu o funkcjonowaniu Unii Europejskiej, dyrektywę 2006/54 UE), a nie do równego wynagradzania pracowników w ogólności; pomija się zatem w tym zakresie inne niż płeć kryteria dyferencjacji. 
nia tego przepisu może prima facie sugerować wniosek, że prawo do równego (jednakowego) wynagrodzenia zostało przez ustawodawcę potraktowane w sposób wyjątkowy, odbiegający od standardu przyjętego w odniesieniu do innych aspektów statusu pracowniczego (takich jak nawiązanie i rozwiązanie stosunku pracy, warunki zatrudnienia, awansowania, dostępu do szkolenia podnoszącego kwalifikacje zawodowe itp.), gdzie explicite zakazem objęte jest różnicowanie przez pracodawcę sytuacji pracowników z przyczyn dyskryminacyjnych (por. art. $18^{3 \mathrm{~b}} \S 1$ k.p.). Natomiast $\mathrm{w}$ treści przypisu art. $18^{3 \mathrm{c}} \mathrm{k} . \mathrm{p}$. ustawodawca wydaje się abstrahować od wyszczególnionych w poprzedzających przepisach k.p. (por. art. $11^{3}$ oraz art. $18^{3 a}$ k.p.) kryteriów zakazanej dyskryminacji (płeć, wiek itp.) i zdaje się wymagać równości absolutnej, gdy porównuje się ze sobą prace jednakowe lub o jednakowej wartości.

Tego rodzaju wykładnia słusznie nie została $\mathrm{w}$ orzecznictwie zaaprobowana. I tak przykładowo w wyroku z dnia 3 czerwca 2014 roku, II PK 126/13 37 , który można uznać za reprezentatywny, Sąd Najwyższy wypowiedział się w sposób następujący: „Podnosząc zarzut dyskryminacji w zakresie wynagradzania [...], pracownik ma obowiązek wykazania nie tylko, że był wynagradzany w sposób mniej korzystny od innych pracowników wykonujących pracę jednakową lub pracę jednakowej wartości, ale również, że takie zróżnicowanie było spowodowane niedozwoloną przyczyną. Wykazanie przez pracownika istnienia określonej przyczyny dyskryminacji jest warunkiem sine qua non dalszego procedowania" 38 .

Tym samym postępowanie w przypadku okoliczności wskazujących na nierówne traktowanie pracowników pod względem płacowym jest w swym ogólnym schemacie analogiczne jak w sytuacji, gdy zachodzi podejrzenie stosowania praktyk dyskryminacyjnych pod jakimkolwiek innym względem. Różnicą jest jedynie występowanie wstępnego etapu uprawdopodobnienia dyskryminacji w postaci zarzutu o stosowanie niejednakowego wynagrodzenia za pracę jednakową lub o jednakowej wartości.

Można wskazać wiele okoliczności usprawiedliwiających nierówności płacowe pozostające w pozornej kolizji z regułą jednakowego wynagrodzenia $\mathrm{z}$ art. $18^{3 \mathrm{c}} \S 1$ k.p. I tak zróżnicowanie wynagrodzeń może być spowodowane przesłankami stażowymi, co nie w każdym przypadku da się wythumaczyć twierdzeniem, że narastanie stażu zwiększa wartość świadczonej pracy. Może też być spowodowane przesłankami związanymi ze strukturą terytorialną przedsiębiorstwa mającego swoje oddziały w różnych regionach kraju. Regionalizacja wynagrodzeń w takim przypadku może

37 „Monitor Prawa Pracy” 2014, nr 10.

38 Por. także należące do tej linii orzeczniczej wcześniejsze wyroki SN z dnia 9 stycznia 2007 roku, II PK 180/06, OSNP 2008/3-4/36 oraz z dnia 18 kwietnia 2012 roku, II PK 196/11, OSNP 2013/7-8/73. Warto zauważyć, że w tym ostatnim orzeczeniu zamiast „obowiązek wykazania” użyto trafniejszych określeń: „obowiązek uprawdopodobnienia” i ,obowiązek przedstawienia faktów, z których można wyprowadzić domniemanie bezpośredniej lub pośredniej dyskryminacji”. 
być uzasadniona sytuacją na lokalnym rynku pracy bądź kształtowaniem się kosztów utrzymania na danym terenie, co ma wpływ na siłę nabywczą wynagrodzeń, a więc uzasadnia ich dyferencjację. Te i inne okoliczności powinny być brane pod uwagę analogicznie jak ma to miejsce w przypadku kontratypu dyskryminacji, gdy pracodawca wprawdzie różnicuje sytuację pracowników z przyczyn uznawanych nominalnie za dyskryminacyjne, ale potrafi udowodnić, że kierował się obiektywnymi powodami (por. art. $18^{3 \mathrm{~b}} \S 1$ k.p. in fine) ${ }^{39}$.

\section{4.}

Warte wzmiankowania są problemy nasuwające się w związku z wykładnią zwrotów „praca jednakowa” oraz „praca jednakowej wartości”, czyli zwrotów pozwalających wyodrębnić kategorię pracowników, wobec których znajduje zastosowanie reguła jednakowego wynagrodzenia. Jak wyżej stwierdzono, nierespektowanie tej reguły w stopniu uznanym za istotny stanowi okoliczność mogącą, przy spełnieniu dalszych warunków, uprawdopodobniać stosowanie przez pracodawcę praktyk dyskryminacyjnych.

Szczególne trudności wiążą się z wykładnią zwrotu „praca o jednakowej wartości”. W art. $18^{3 c} \S 3$ k.p. wskazuje się na tradycyjne przesłanki wartościowania pracy (kwalifikacje zawodowe, odpowiedzialność, wysiłek). Zwraca uwage pominięcie w tym zestawie warunków, w jakich praca jest świadczona (praca bezpieczna versus stwarzająca zagrożenie dla życia i zdrowia, praca uciążliwa i monotonna versus przebiegająca w warunkach komfortowych), oraz brak odniesienia się do kryteriów efektywnościowych ${ }^{40}$. Niewątpliwie jednak należy zgodzić się z twierdzeniem, że wartościowanie pracy we wszystkich wskazanych wyżej aspektach jest nie tylko niezbędnym warunkiem zapewnienia ekwiwalentności świadczeń wzajemnych (por. pkt 10), ale również warunkiem respektowania zasady równego traktowania pracowników w warunkach zatrudnienia $\mathrm{w}$ jednym zakładzie pracy przy pracach różniących się rodzajem i charakterystyką. Wprowadzenie obowiązku wartościowania pracy w stosunku do pracodawców zatrudniających większą oraz zróżnicowaną pod względem zawodowym i stanowiskowym liczbę pracowników należy uznać za postulat de lege ferend $a^{41}$.

39 Rozważając problematykę równego traktowania pracowników w zakresie płac, pominąłem - z uwagi na potrzebę zachowania zawartości tematycznej opracowania - złożony problem ochrony poufności jednostkowych wynagrodzeń w konfrontacji z możliwością dochodzenia roszczeń z tytułu domniemanej dyskryminacji.

40 Na przykład w systemie wartościowania pracy Haya kluczową przesłanką braną pod uwagę przy ocenie stanowisk pracy jest jego znaczenie dla funkcjonowania organizacji gospodarczej.

${ }^{41}$ Por. K. Walczak, Wartościowanie stanowisk pracy prawnym obowiąziem pracodawcy?, „Monitor Prawniczy” 2004, nr 9. 


\section{PODSUMOWANIE}

W zakresie podstaw aksjologicznych wynagrodzenia za pracę ścierają się ze sobą dwie koncepcje sprawiedliwości. Pierwsza, będąca przejawem sprawiedliwości rozdzielczej (dystrybutywnej), pozwala mówić o płacy zaspokajającej potrzeby pracownika i jego rodziny. Jest to tzw. zasada finalna. Druga, będąca przejawem sprawiedliwości wzajemnej (komutatywnej), pozwala mówić o płacy jako świadczeniu wzajemnym i ekwiwalentnym względem pracy. Jest to tzw. zasada kauzalna. Obie zasady są przejawem sprawiedliwości konkretnej (materialnej) według koncepcji Perelmana.

Wymienny charakter świadczeń między stronami (według formuły facio ut des) może sugerować cywilistyczny i towarowy charakter wzajemnej więzi. Należy jednak podkreślić, że w porządku etycznym zasada finalna ma pierwszeństwo przed zasadą kauzalną. W wielu stosunkach pracy wynagrodzenie rozumiane jako ekwiwalent świadczenia pracy odpowiada wprawdzie idei płacy życiowej i rodzinnej, lecz w innych potrzebna jest korektura będąca efektem polityki państwa i innych podmiotów, mającej na celu zaspokojenie przynajmniej podstawowe potrzeby pracowników. Głównym narzędziem interwencji w tym zakresie jest instytucja wynagrodzenia minimalnego. Wynagrodzenie minimalne $\mathrm{w}$ aktach prawa międzynarodowego i europejskiego, jak również w licznych enuncjacjach programowych, w tym zwłaszcza w dokumentach społecznego nauczania Kościoła, wynagrodzenie minimalne jest kojarzone z pojęciem godziwości wynagrodzenia za pracę, które występuje również w polskim kodeksie pracy. Wynagrodzenie godziwe ma zapewnić rodzinom pracowniczym utrzymanie na właściwym poziomie w relacji do ogólnego poziomu płac w danym kraju. Na uwagę zasługuje postulat rozciągnięcia kategorii wynagrodzenia minimalnego na pozapracownicze stosunki zatrudnienia. Drugą funkcją, jaka została przypisana do koncepcji wynagrodzenia godziwego, jest niedopuszczenie do nadmiernego wywindowania płac, co dotyczy zwłaszcza wynagrodzeń osób zatrudnionych w sektorze publicznym. Znajduje wówczas zastosowanie dewiza sprawiedliwości rozdzielczej „według przyzwoitości w czerpaniu na wynagrodzenia ze środków publicznych”.

W przypadku zasady kauzalnej, będącej przejawem sprawiedliwości wymiennej, podstawowego znaczenia nabiera kwestia ekwiwalentności świad- 
czeń wzajemnych, z czym wiąże się złożony problem pomiaru pracy na użytek wyznaczania wysokości wynagrodzeń. Przybliżeniu się do wzorca płacy ekwiwalentnej w danych warunkach służy procedura wartościowania pracy. Postulatem de lege ferenda jest wprowadzenie obowiązku wartościowania pracy w stosunku do pracodawców zatrudniających większą i zróżnicowaną pod względem zawodowym i stanowiskowym liczbę pracowników.

Dla ustalenia uprawnień płacowych prawnie rozstrzygające znaczenie mają rokowania indywidualne nad klauzulami płacowymi umowy o pracę oraz zbiorowe nad treścią autonomicznych źródeł prawa pracy. Samoistną wartością w tym przypadku jest negocjowalność warunków wynagradzania. Odnosząc się do rokowań zbiorowych, należy podkreślić, że w ich trakcie dochodzi do głosu poczucie sprawiedliwości partnerów społecznych, w wyniku czego wytyczne postulaty wywodzone z przekonania o tym, jakie wynagrodzenia należy uznać za godziwe, mogą podlegać jurydyzacji (np. ustalenie wysokości płac w proporcji do dochodu przedsiębiorstwa).

Odrębna pod pewnymi względami problematyka wiąże się z zasadą równości w zakresie wynagrodzeń, będąca przejawem tzw. sprawiedliwości formalnej. Jej wyrazem w kodeksie pracy jest w szczególności przepis art. $18^{3 \mathrm{c}}$ ustanawiający prawo pracowników do jednakowego wynagrodzenia za pracę jednakową lub za pracę o jednakowej wartości. Zgodnie z akceptowanym przez autora orzecznictwem SN wykładnia tego przepisu powinna być dokonywana w powiązaniu z całokształtem antydyskryminacyjnych przepisów kodeksu pracy. Powołanie się na art. $18^{3 \mathrm{c}} \mathrm{k}$.p. stanowi jedynie wstępny etap uprawdopodobnienia przez pracownika praktyk dyskryminacyjnych. Pracodawca, konfrontując się z zarzutem o dyskryminację, powinien udowodnić, że różnicując sytuację pracowników, kierował się obiektywnymi powodami. Stwarza to przestrzeń dla uzasadnionej dy ferencjacji wynagrodzeń (np. w wymiarze regionalnym).

Kodeksowa definicja „,pracy o jednakowej wartości” jest w przekonaniu autora niewyczerpująca i konserwatywna. Więcej przestrzeni należy pozostawić dla zamanifestowania ocen partnerów społecznych w procesie stanowienia zakładowego prawa pracy.

\section{BIBLIOGRAFIA}

Arystoteles, Etyka nikomachejska, przeł. D. Gromska, Warszawa 1956.

Boruta I., Prawo pracownic do jednakowego wynagrodzenia, „Praca i Zabezpieczenie Społeczne” 1991, nr 11-23.

Boruta I., Zakaz dyskryminacji płacowej ze względu na płeć w prawie WE, „Praca i Zabezpieczenie Społeczne" 1995, nr 11. 
Dyczewski L., Ptaca sprawiedliwa i stuszna, „Ethos” 1995, nr 4.

Dyczewski L., Stuszna i sprawiedliwa płaca w ujęciu katolickiej nauki społecznej, [w:] Prawo do płacy godziwej, Warszawa 1994.

Głogowska M., Płeć jako kryterium dyskryminacji lub dyferencjacji w zakresie wynagradzania, „Studia z Zakresu Prawa Pracy i Polityki Społecznej” 2014.

Głogowska M., Zakres przedmiotowy zakazu dyskryminacji w wynagradzaniu ze względu na płeć w orzecznictwie ETS, „Studia z Zakresu Prawa Pracy i Polityki Społecznej” 2012.

Grzybowski S., System prawa cywilnego. Część ogólna, Wrocław 1974.

Jan Paweł II, Centesimus Annus (w setna rocznicę Encykliki Rerum Novarum), [w:] Dzieła zebrane, Kraków 2006.

Jan Paweł II, Laborem exercens, Wrocław 1983.

Konwencje i zalecenia Międzynarodowej Organizacji Pracy 1919-2012, t. 2: 1974-2012, Ministerstwo Pracy i Polityki Społecznej, Warszawa 2014.

Liszcz T., Równość kobiet i mężczyzn w k.p., „Praca i Zabezpieczenie Społeczne” 2002, nr 2.

Majka Z., Etyka życia gospodarczego, Wrocław 1982.

Meller J., Ptaca godziwa i jej determinanty, [w:] Prawo do pracy godziwej, Warszawa 1994.

Nowak M., Wynagrodzenie za prace, Warszawa 2014.

Perelman Ch., O sprawiedliwości, Warszawa 1959.

Podstawowe dokumenty Rady Europy z dziedziny polityki społecznej, wyb. i oprac. R. Henczel, J. Maciejewska, Warszawa 1997.

Rawls J., Teoria sprawiedliwości, Warszawa 1994.

Sadurski W., Równość wobec prawa, „Państwo i Prawo” 1978, nr 8-9.

Sanetra W., Ogólnie o aksjologicznych podstawach prawa pracy, „Praca i Zabezpieczenie Społeczne" 2013, nr 11 .

Skoczyński J., Zasada równego traktowania pracowników, „Praca i Zabezpieczenie Społeczne"1999, nr 7-8.

Sobczyk A., Prawo pracy w świetle Konstytucji RP, t. 2: Wybrane problemy i instytucje prawa pracy a konstytucyjne prawa $i$ wolności człowieka, Warszawa 2013.

Sobczyk A., Wynagrodzenie minimalne zleceniobiorców, „Praca i Zabezpieczenie Społeczne” 2012, nr 8.

Świderska K., Zakaz dyskryminacji w wynagradzaniu, „Monitor Prawniczy” 2004, nr 5.

Tyc A., Możliwość zakwalifikowania interesu ekonomicznego jako obiektywnego kryterium uzasadniającego zróżnicowanie pracowników a realizacja zasad równości i sprawiedliwości, [w:] Studia z zakresu prawa pracy i polityki społecznej, pod red. A. Świątkowskiego, Kraków 2013.

Wagner B., Zasada równego traktowania i niedyskryminacji pracowników, „Praca i Zabezpieczenie Społeczne" 2002, nr 3.

Walczak K., Regionalizacja wynagrodzeń a zasada niedyskryminacji pracowników, „Gdańskie Studia Prawnicze" 2013, t. XXX.

Walczak K., Wartościowanie stanowisk pracy prawnym obowiąkiem pracodawcy?, „Monitor Prawniczy" 2004, nr 9.

Walczak K., Zakaz dyskryminacji w wynagrodzeniu w świetle przepisów prawa i praktyka jego wdrażania, „Studia z Zakresu Prawa Pracy i Polityki Społecznej” 2005, nr 1.

Wandzel M., Równe traktowanie mężczyzn i kobiet, Kraków 2003.

Wandzel M., Wynagrodzenie proporcjonalne do wartości pracy jako realizacja zasady równego wynagradzania pracowników za taka sama pracę lub pracę o takiej samej wartości w prawie wspólnotowym, „Studia z Zakresu Prawa Pracy i Polityki Społecznej” 2009.

Wratny J., Koncepcja pracy sprawiedliwej a niektóre aktualne problemy prawa pracy i polityki płac w Polsce, „Ethos” 1995, nr 4.

Wratny J., Ptaca rodzinna (szkic zagadnienia), [w:] Prawo pracy a rodzina. Uktady zbiorowe pracy, pod red. T. Liszcz, Warszawa 1996, Warszawa 1996.

Zalewski T., Płaca minimalna nie przy każdym zleceniu, „Dziennik Gazeta Prawna”, 05.11.2014. 


\section{SUMMARY}

In terms of axiology of fair remuneration for work two concepts compete - on the one hand remuneration seen as a means to serving needs of the worker and his family (final rule), and on the other hand the concept of equivalence for work (the principle of causa). The realization of the final rule is an institution of the minimum wage. The principle of causa requires the methods of job evaluation. Other aspect of fair compensation is the principle of equality, which is reflected particularly by the provision of art. $18^{3 \mathrm{c}}$ of Polish Labour Code. The reference to this provision represents a preliminary stage of prima facie evidence of the employee's discriminatory practices. An employer may oppose the indication of discrimination by proving that their activity were guided by justified reasons, which creates space for a reasonable differentiation of wages in the workplace.

Keywords: remuneration for work; justice; equality; discrimination 